\title{
Alternative Utilization of Protein-Rich Waste by Its Conversion into Biogas in Co-Fermentation Conditions
}

\author{
Piotr Sakiewicz ${ }^{1}$, Krzysztof Piotrowski ${ }^{2 *}$, Jan Cebula ${ }^{3}$, Jolanta Bohdziewicz ${ }^{4}$ \\ ${ }^{1}$ Faculty of Mechanical Engineering, Institute of Engineering Materials and Biomaterials, Unit of Nanocrystalline \\ and Functional Materials and Sustainable Proecological Technologies, Silesian University of Technology in Gliwice \\ ${ }^{2}$ Faculty of Chemistry, Department of Chemical Engineering and Process Design, \\ Silesian University of Technology in Gliwice, ks. M. Strzody 7, 44-101 Gliwice, Poland \\ ${ }^{3}$ Faculty of Materials and Environmental Sciences, Institute of Environmental Protection and Engineering, \\ Unit of Environmental Processes and Technologies, University of Bielsko-Biała \\ ${ }^{4}$ Faculty of Energy and Environmental Engineering, Institute of Water and Wastewater Engineering, \\ Unit of Environmental Chemistry and Membrane Processes, \\ Silesian University of Technology in Gliwice
}

Received: 7 October 2016

Accepted: 31 December 2016

\begin{abstract}
The recommended process conditions and problems reported during anaerobic (co-)fermentation of waste biomass rich in proteins are discussed. Theoretical potentials of the individual biogas components $\left(\mathrm{CH}_{4}, \mathrm{CO}_{2}, \mathrm{NH}_{3}, \mathrm{H}_{2} \mathrm{~S}\right)$ formed during chemical decomposition of aminoacids - feed additives commonly used in feeding animals - are shown, and we discuss side production of odors, e.g., ammonia and organic sulphur compounds. We also suggest the potential alternative production of biohydrogen (a future energy carrier) from specific waste biomass with high protein content.
\end{abstract}

Keywords: anaerobic fermentation, co-fermentation, biomass, proteins, aminoacids, animal breeding wastes, dairy wastes, biomethane, biohydrogen, odors

\section{Introduction}

A large amount of litter is generated in industrial-scale animal breeding, and this is recognized as a big problem in animal-breeding technology. Troublesome waste may, however, be regarded as a useful, easily accessible cosubstrate for the production of biogas and semi-liquid residue suitable for fertilizing plants. Its utilization

*e-mail: Krzysztof.Piotrowski@polsl.pl problem can thus be integrated with the production of an environmentally friendly energy carrier: biomethane. The results of litter decomposition are visible just after excretion as odor compounds are emitted. Animal litter of high protein concentration and moisture $>40 \%$ undergoes complex biochemical decomposition that is closely related to the intensive emission of ammonia. It directly affects living conditions of animals in rooms [1]. The amount and composition of the gaseous mixture produced from litter depends, among other things, on: temperature, moisture level, mixing frequency, bedding type, composition and 
structure, and bedding crumble. For practical purposes the general biomass decomposition route provided by the Buswell formula [2] is in use:

$$
\begin{aligned}
& \mathrm{C}_{\mathrm{c}} \mathrm{H}_{\mathrm{h}} \mathrm{O}_{\mathrm{o}} \mathrm{N}_{\mathrm{n}} \mathrm{S}_{\mathrm{s}}+y \mathrm{H}_{2} \mathrm{O} \rightarrow x \mathrm{CH}_{4} \\
& +(c-x) \mathrm{CO}_{2}+n \mathrm{NH}_{3}+s \mathrm{H}_{2} \mathrm{~S}
\end{aligned}
$$

...where $c, h, o, n$, and $s$ are, respectively, carbon, hydrogen, oxygen, nitrogen, and sulphur moles in 1 mole of a given biomass compound; $x=0.125(4 c+h-2 o-3 n$ $+2 s)$; and $\mathrm{y}=0.250(4 c-h-2 o+3 n+2 s)$.

Litter decomposition products are directly correlated with its chemical composition, process conditions, and fodder type. Each farm animal, at various ages, may have specific dietary requirements covering, for example, food amount, dosing frequency, nutrient composition, etc. The fodder prepared specially for poultry, for example, includes fodder oils, vegetable and animal proteins, chalk, specimens, substitute milk, fodder phosphate $(\mathrm{V})$, cereal seed, etc. Average protein content in a fodder designated for poultry is usually ca. $20 \%$ and is usually provided to the animals in the form of specially prepared fodder components like soy and/or rapeseed meal, sunflower or/and rape oilcake, wheat bran, distillery infusion, beet pulp, or brewery spent grain residues. Animal proteins are also purposefully added to fodder, usually as fish meal, hemoglobin, and/or blood plasma. Protein decomposition starts from their hydrolysis to peptides and aminoacids. The process is driven by external enzymes (proteases). Some bacteria strains in a ruminant's stomach (Streptococus bovis, Lactobacillus or Ruminobacter, Ruminococcus) are responsible for the processes of carbohydrate fermentation that decomposes proteins and aminoacids. For many breeding animals, anaerobic decomposition of the fodder components runs as early as in their alimentary canals.

Some fraction of food industry wastes, especially dairy wastes, is consumed by animals on farms (fodder milk, dry casein, waste meat) [3]. Although dairy wastes covering casein can be partly recycled in various branches of food industry, in general these are regarded as troublesome wastes - not toxic, but with high oxidation requirements to decompose. For this reason these are dangerous for the natural environment and should be safely utilized, e.g., by the methane (co-)fermentation process [4-5], in spite of its inhibiting effect on the digestion course.

The objective of this paper is to analyze the anaerobic (co-)digestion potential of the protein-rich biomass, considered primarily as a convenient method of its safe utilization as a co-substrate or additive. In particular,

\begin{tabular}{|c|c|c|c|c|c|c|c|}
\hline No. & Aminoacid & $\begin{array}{l}\text { Molar mass } \\
\quad(\mathrm{g} / \mathrm{mol})\end{array}$ & Chemical formula & $\begin{array}{c}\mathrm{CH}_{4} \\
\text { moles }\end{array}$ & $\mathrm{CO}_{2}$ moles & $\mathrm{NH}_{3}$ moles & $\mathrm{H}_{2} \mathrm{~S}$ moles \\
\hline 1 & Alanine & 89.09 & $\mathrm{C}_{3} \mathrm{H}_{7} \mathrm{NO}_{2}$ & 1.50 & 1.50 & 1 & 0 \\
\hline 2 & Arginine & 174.20 & $\mathrm{C}_{6} \mathrm{H}_{14} \mathrm{~N}_{4} \mathrm{O}_{2}$ & 2.75 & 3.25 & 4 & 0 \\
\hline 3 & Asparagine & 132.12 & $\mathrm{C}_{4} \mathrm{H}_{8} \mathrm{~N}_{2} \mathrm{O}_{3}$ & 1.50 & 2.50 & 2 & 0 \\
\hline 4 & Aspartic acid & 133.10 & $\mathrm{C}_{4} \mathrm{H}_{7} \mathrm{NO}_{4}$ & 1.50 & 2.50 & 1 & 0 \\
\hline 5 & Cysteine & 121.16 & $\mathrm{C}_{3} \mathrm{H}_{7} \mathrm{NO}_{2} \mathrm{~S}$ & 1.75 & 1.25 & 1 & 1 \\
\hline 6 & Glutamine & 146.15 & $\mathrm{C}_{5} \mathrm{H}_{10} \mathrm{~N}_{2} \mathrm{O}_{3}$ & 2.25 & 2.75 & 2 & 0 \\
\hline 7 & Glutamic acid & 147.13 & $\mathrm{C}_{5} \mathrm{H}_{9} \mathrm{NO}_{4}$ & 2.25 & 2.75 & 1 & 0 \\
\hline 8 & Glycine & 75.07 & $\mathrm{C}_{2} \mathrm{H}_{5} \mathrm{NO}_{2}$ & 0.75 & 1.25 & 1 & 0 \\
\hline 9 & Histidine & 155.16 & $\mathrm{C}_{6} \mathrm{H}_{9} \mathrm{~N}_{3} \mathrm{O}_{2}$ & 2.50 & 3.50 & 3 & 0 \\
\hline 10 & Isoleucine & 131.17 & $\mathrm{C}_{6} \mathrm{H}_{13} \mathrm{NO}_{2}$ & 3.75 & 2.25 & 1 & 0 \\
\hline 11 & Leucine & 131.17 & $\mathrm{C}_{6} \mathrm{H}_{13} \mathrm{NO}_{2}$ & 3.75 & 2.25 & 1 & 0 \\
\hline 12 & Lysine & 146.19 & $\mathrm{C}_{6} \mathrm{H}_{14} \mathrm{~N}_{2} \mathrm{O}_{2}$ & 3.50 & 2.50 & 2 & 0 \\
\hline 13 & Methionine & 149.21 & $\mathrm{C}_{5} \mathrm{H}_{11} \mathrm{NO}_{2} \mathrm{~S}$ & 3.25 & 1.75 & 1 & 1 \\
\hline 14 & Phenylalanine & 165.19 & $\mathrm{C}_{9} \mathrm{H}_{11} \mathrm{NO}_{2}$ & 5.00 & 4.00 & 1 & 0 \\
\hline 15 & Proline & 115.13 & $\mathrm{C}_{5} \mathrm{H}_{9} \mathrm{NO}_{2}$ & 2.75 & 2.25 & 1 & 0 \\
\hline 16 & Serine & 105.09 & $\mathrm{C}_{3} \mathrm{H}_{7} \mathrm{NO}_{3}$ & 1.25 & 1.75 & 1 & 0 \\
\hline 17 & Threonine & 119.12 & $\mathrm{C}_{4} \mathrm{H}_{9} \mathrm{NO}_{3}$ & 2.00 & 2.00 & 1 & 0 \\
\hline 18 & Tryptophan & 204.23 & $\mathrm{C}_{11} \mathrm{H}_{12} \mathrm{~N}_{2} \mathrm{O}_{2}$ & 5.75 & 5.25 & 2 & 0 \\
\hline 19 & Tyrosine & 181.19 & $\mathrm{C}_{9} \mathrm{H}_{11} \mathrm{NO}_{3}$ & 4.75 & 4.25 & 1 & 0 \\
\hline 20 & Valine & 117.15 & $\mathrm{C}_{5} \mathrm{H}_{11} \mathrm{NO}_{2}$ & 3.00 & 2.00 & 1 & 0 \\
\hline
\end{tabular}

Table 1. Theoretical numbers of moles of $\mathrm{CH}_{4}, \mathrm{CO}_{2}, \mathrm{NH}_{3}$, and $\mathrm{H}_{2} \mathrm{~S}$ produced from the decomposition of 1 mole of individual aminoacids. 
theoretical prediction of biogas main components yields $\left(\mathrm{CH}_{4}, \mathrm{CO}_{2}, \mathrm{NH}_{3}, \mathrm{H}_{2} \mathrm{~S}\right)$ was done based on chemical decomposition schemes of the aminoacids. The side production of ammonia and odorous sulphur compounds, as well as biohydrogen, was also discussed.

\section{Aminoacids as the Substrates for Biogas Production}

Different biogas yields can be observed during anaerobic fermentation of various chemically pure aminoacids (pure reference substances). This is an effect of different biotechnological paths - methane fermentation schemes of specific aminoacids [6]:

- $\quad 3 \mathrm{C}_{3} \mathrm{H}_{7} \mathrm{O}_{2} \mathrm{~N}+3 \mathrm{H}_{2} \mathrm{O} \rightarrow \mathrm{CH}_{3} \mathrm{COOH}+$

$2 \mathrm{CH}_{3} \mathrm{CH}_{2} \mathrm{COOH}+3 \mathrm{NH}_{3}+\mathrm{CO}_{2}+\mathrm{H}_{2}$

- $\mathrm{C}_{3} \mathrm{H}_{7} \mathrm{O}_{2} \mathrm{~N}+\mathrm{H}_{2} \mathrm{O} \rightarrow 0.5 \mathrm{CH}_{3} \mathrm{CH}_{2} \mathrm{CH}_{2} \mathrm{COOH}+\mathrm{NH}_{3}$ $+\mathrm{CO}_{2}+\mathrm{H}_{2}$

- $\mathrm{C}_{3} \mathrm{H}_{7} \mathrm{O}_{3} \mathrm{~N}+\mathrm{H}_{2} \mathrm{O} \rightarrow \mathrm{CH}_{3} \mathrm{COOH}+\mathrm{NH}_{3}+\mathrm{CO}_{2}+\mathrm{H}_{2}$

- $\mathrm{C}_{3} \mathrm{H}_{7} \mathrm{O}_{3} \mathrm{~N} \rightarrow 0.5 \mathrm{C}_{4} \mathrm{H}_{8} \mathrm{O}_{2}+\mathrm{NH}_{3}+\mathrm{CO}_{2}$

- $\mathrm{C}_{4} \mathrm{H}_{7} \mathrm{O}_{4} \mathrm{~N}+2 \mathrm{H}_{2} \mathrm{O} \rightarrow \mathrm{CH}_{3} \mathrm{COOH}+\mathrm{NH}_{3}+2 \mathrm{CO}_{2}$ $+2 \mathrm{H}_{2}$

- $\mathrm{C}_{4} \mathrm{H}_{7} \mathrm{O}_{4} \mathrm{~N} \rightarrow \mathrm{C}_{3} \mathrm{H}_{7} \mathrm{O}_{2} \mathrm{~N}+\mathrm{CO}_{2}$

- $\mathrm{C}_{6} \mathrm{H}_{13} \mathrm{O}_{2} \mathrm{~N}+2 \mathrm{H}_{2} \mathrm{O} \stackrel{2}{\rightarrow} \mathrm{C}_{5} \mathrm{H}_{10} \mathrm{O}_{2}+\mathrm{NH}_{3}+\mathrm{CO}_{2}+2 \mathrm{H}_{2}$
Theoretical numbers of moles (thus volumes under normal conditions) of methane, carbon dioxide, ammonia, and hydrogen sulphide that might form during anaerobic fermentation of 1 mole of the individual aminoacid are presented in Table 1 (total chemical conversion is assumed).

Table 2 shows the biogas volumes that can be produced from 1 mole of aminoacid and from $1 \mathrm{~g}$ of aminoacid in normal conditions.

The largest volumes of biogas can be obtained from waste proteins containing tryptophan, phenylalanine, and tyrosine. Tryptophan and phenylalanine are the aminoacids indispensable for many metabolic paths. Most often these are present in component feeds in the form of leguminous plants, cereal products, vegetables, and fruits. Most of these aminoacids are used in poultry breeding. In respect to the maximization of biogas production, the best raw materials seem to be phenylalanine, tryptophan, tyrosine, and leucine. The unwanted components fraction in biogas (e.g., $\mathrm{H}_{2} \mathrm{~S}$ ) from cysteine decomposition is $20 \%$, whereas in the case of methionine it is $14.28 \%$. These components must be removed from the biogas because of many unwanted properties (highly corrosive properties). The high biogas yield observed in the case of methane

Table 2. Biogas volumes that can be produced from 1 mole of aminoacid and from $1 \mathrm{~g}$ of aminoacid in normal conditions.

\begin{tabular}{|c|c|c|c|c|}
\hline No. & Aminoacid & Chemical formula & $\begin{array}{l}\text { Volume of biogas produced from } 1 \\
\text { mole of aminoacid } \\
\left(\mathrm{dm}^{3}\right)\end{array}$ & $\begin{array}{l}\text { Volume of biogas produced from } 1 \mathrm{~g} \\
\text { of aminoacid } \\
\qquad\left(\mathrm{dm}^{3}\right)\end{array}$ \\
\hline 1 & Alanine & $\mathrm{C}_{3} \mathrm{H}_{7} \mathrm{NO}_{2}$ & 68.22 & 0.77 \\
\hline 2 & Arginine & $\mathrm{C}_{6} \mathrm{H}_{14} \mathrm{~N}_{4} \mathrm{O}_{2}$ & 138.46 & 0.79 \\
\hline 3 & Asparagine & $\mathrm{C}_{4} \mathrm{H}_{8} \mathrm{~N}_{2} \mathrm{O}_{3}$ & 89.63 & 0.68 \\
\hline 4 & Aspartic acid & $\mathrm{C}_{4} \mathrm{H}_{7} \mathrm{NO}_{4}$ & 90.63 & 0.68 \\
\hline 5 & Cysteine & $\mathrm{C}_{3} \mathrm{H}_{7} \mathrm{NO}_{2} \mathrm{~S}$ & 90.64 & 0.75 \\
\hline 6 & Glutamine & $\mathrm{C}_{5} \mathrm{H}_{10} \mathrm{~N}_{2} \mathrm{O}_{3}$ & 114.05 & 0.78 \\
\hline 7 & Glutamic acid & $\mathrm{C}_{5} \mathrm{H}_{9} \mathrm{NO}_{4}$ & 113.05 & 0.77 \\
\hline 8 & Glycine & $\mathrm{C}_{2} \mathrm{H}_{5} \mathrm{NO}_{2}$ & 45.82 & 0.61 \\
\hline 9 & Histidine & $\mathrm{C}_{6} \mathrm{H}_{9} \mathrm{~N}_{3} \mathrm{O}_{2}$ & 137.45 & 0.89 \\
\hline 10 & Isoleucine & $\mathrm{C}_{6} \mathrm{H}_{13} \mathrm{NO}_{2}$ & 135.45 & 1.03 \\
\hline 11 & Leucine & $\mathrm{C}_{6} \mathrm{H}_{13} \mathrm{NO}_{2}$ & 135.45 & 1.03 \\
\hline 12 & Lysine & $\mathrm{C}_{6} \mathrm{H}_{14} \mathrm{~N}_{2} \mathrm{O}_{2}$ & 136.45 & 0.93 \\
\hline 13 & Methionine & $\mathrm{C}_{5} \mathrm{H}_{11} \mathrm{NO}_{2} \mathrm{~S}$ & 135.46 & 0.91 \\
\hline 14 & Phenylalanine & $\mathrm{C}_{9} \mathrm{H}_{11} \mathrm{NO}_{2}$ & 202.69 & 1.23 \\
\hline 15 & Proline & $\mathrm{C}_{5} \mathrm{H}_{9} \mathrm{NO}_{2}$ & 113.05 & 0.98 \\
\hline 16 & Serine & $\mathrm{C}_{3} \mathrm{H}_{7} \mathrm{NO}_{3}$ & 68.23 & 0.65 \\
\hline 17 & Threonine & $\mathrm{C}_{4} \mathrm{H}_{9} \mathrm{NO}_{3}$ & 90.64 & 0.76 \\
\hline 18 & Tryptophan & $\mathrm{C}_{11} \mathrm{H}_{12} \mathrm{~N}_{2} \mathrm{O}_{2}$ & 248.51 & 1.22 \\
\hline 19 & Tyrosine & $\mathrm{C}_{9} \mathrm{H}_{11} \mathrm{NO}_{3}$ & 202.69 & 1.12 \\
\hline 20 & Valine & $\mathrm{C}_{5} \mathrm{H}_{11} \mathrm{NO}_{2}$ & 113.05 & 0.97 \\
\hline
\end{tabular}


fermentation of poultry litter can be related to incomplete digestion of the feed by animals, spreading of the feed, and the occurrence of too large an amount of high-protein and fat fractions [7-9].

\section{Technological Process Constraints}

We observed the inhibiting effect of system salinity on the methane fermentation process. This toxic effect results from increased concentrations of sodium, potassium, and ammonium ions. Ammonium nitrogen content affects the biogas production process yield significantly. This distinct trend is well documented and has been reported by various researchers [10]. This trend is clearly observed - especially in the case of thermophilic fermentation variant. Concentrations above $8 \mathrm{~g}$ of $\mathrm{NaCl}$ in the fermentation chamber can decrease biogas production rate by up to $80 \%$ [11].

Total nitrogen content in a fermented mixture can be high. Nevertheless, it must be raised gradually. At pH 6.6 total nitrogen content in a fermentation system can even reach $18.3 \mathrm{~g} / \mathrm{dm}^{3}$ [12-14]. The effect of concentration of ammonia produced during methane fermentation of

Table 3. Characteristics of decomposition products of casein, albumin, and collagen.

\begin{tabular}{|c|c|c|c|}
\hline Protein type & Casein & Albumin & Collagen \\
\hline $\begin{array}{l}\text { Amount of } \mathrm{CH}_{4} \text { moles } \\
\text { from } 1 \text { mole of aminoacid } \\
\text { according to the Buswell } \\
\text { formula }\end{array}$ & 2.73 & 2.77 & 1.81 \\
\hline $\begin{array}{l}\text { Amount of } \mathrm{CO}_{2} \text { moles } \\
\text { from } 1 \text { mole of aminoacid } \\
\text { according to the Buswell } \\
\text { formula }\end{array}$ & 2.48 & 2.47 & 1.86 \\
\hline $\begin{array}{l}\text { Amount of } \mathrm{NH}_{3} \text { moles } \\
\text { from } 1 \text { mole of aminoacid } \\
\text { according to the Buswell } \\
\text { formula }\end{array}$ & 1.21 & 1.27 & 1.16 \\
\hline $\begin{array}{l}\text { Amount of } \mathrm{H}_{2} \mathrm{~S} \text { moles } \\
\text { from } 1 \text { mole of aminoacid } \\
\text { according to the Buswell } \\
\text { formula }\end{array}$ & 0.03 & 0.05 & 0.01 \\
\hline Molar mass, g/mol & 133.20 & 134.45 & 102.27 \\
\hline $\begin{array}{c}\text { Volume of } \mathrm{CH}_{4} \text { from } 1 \text { mole } \\
\text { of protein, } \mathrm{dm}^{3}\end{array}$ & 61.18 & 62.07 & 40.56 \\
\hline $\begin{array}{l}\text { Volume of } \mathrm{CO}_{2} \text { from } 1 \text { mole } \\
\text { of protein, } \mathrm{dm}^{3}\end{array}$ & 55.57 & 55.35 & 41.68 \\
\hline $\begin{array}{l}\text { Volume of } \mathrm{NH}_{3} \text { from } 1 \text { mole } \\
\text { of protein, } \mathrm{dm}^{3}\end{array}$ & 27.12 & 28.46 & 25.99 \\
\hline $\begin{array}{l}\text { Volume of } \mathrm{H}_{2} \mathrm{~S} \text { from } 1 \text { mole } \\
\text { of protein, } \mathrm{dm}^{3}\end{array}$ & 0.67 & 1.12 & 0.22 \\
\hline $\begin{array}{c}\text { Volume of biogas from } 1 \\
\text { mole of protein, } \mathrm{dm}^{3}\end{array}$ & 6.45 & 6.56 & 4.84 \\
\hline $\begin{array}{l}\text { Volume of biogas from } 1 \mathrm{~g} \\
\text { of protein, } \mathrm{dm}^{3}\end{array}$ & 0.048 & 0.049 & 0.047 \\
\hline
\end{tabular}

fish meal on the decomposition rate of anaerobically fermented wastes is described by Omil, Mendez, and Lema [15]. During methane fermentation of poultry litter (domestic fowl) one can observe a characteristic longer period of the lag phase, which can last as long as nine days [16]. The higher the poultry litter and protein content in the anaerobically fermented mixture, the longer this accommodation phase [17]. The fermentation process course of bone-meat meal of $10 \%$ dry mass content was also described in [18]. Sparingly decomposable biomass can undergo hydrolysis in a basic environment. The higher the $\mathrm{pH}$ of the aqueous environment, the faster the observed hydrolysis. High ammonia content in a hydrolyzed biomass sludge thus causes fast decomposition of sparingly decomposable biomass fraction [19]. From 1 mole of protein in a form of casein of chemical formula $\mathrm{C}_{5.21} \mathrm{H}_{9.92} \mathrm{O}_{2.67} \mathrm{~N}_{1.21} \mathrm{~S}_{0.03}$ after fermentation it is possible to obtain 2.73 moles of methane. After fermentation of 1 mole of protein in a form of albumin of chemical formula $\mathrm{C}_{5.24} \mathrm{H}_{10.13} \mathrm{O}_{2.62} \mathrm{~N}_{1.27} \mathrm{~S}_{0.05}$ one can obtain 2.77 moles of methane, whereas during fermentation of protein in a chemical form of collagen of chemical formula $\mathrm{C}_{3.67} \mathrm{H}_{7.49} \mathrm{O}_{2.13} \mathrm{~N}_{1.16} \mathrm{~S}_{0.01}$ from 1 mole we can obtain 1.81 moles of methane (Table 3 ).

Casein, albumin, and collagen, depending on temperature, undergo $76-89 \%$ biodegradation. The chemical structure of proteins is a main factor determining their hydrolysis degree, thus their ability to biodegrade. For example, anaerobic fermentation of animal leather depends on its callous degree. The leather tanned with chromium-based tans ferments longer compared to leather being tanned only with vegetable tans. Tanned leather demands a longer time for hydrolysis (ca. 15-30 days on average), whereas non-tanned leather is a subject of biodegradation within ca. seven days [20].

Using poultry litter as a co-substrate is connected with the production of excess amounts of ammonium nitrogen, which is regarded as a big technological problem that requires some technological overcoming methods. In spite of various technological approaches and research effort this problem remains practically unsolved. Some technological approaches toward this problem involve the introduction of various additives like acidic acid, or affect the metabolism rate of methanogenic bacteria through the lower supply of the nutrients.

\section{Possibility of Alternative Biohydrogen Production}

During anaerobic decomposition of aminoacids hydrogen is also produced, which can potentially be of primary importance, e.g., for the energetic strategy of biogas plant designed as some kind of biorefinery, with the possibility of processing conditions modification toward biogas or biohydrogen production, depending on the current market needs. Such reaction schemes can be presented in the form of the following stoichiometric equations [21]:

- $\mathrm{RCH}\left(\mathrm{NH}_{2}\right) \mathrm{COOH}+\mathrm{H}_{2} \mathrm{O} \rightarrow \mathrm{RCOCOOH}+\mathrm{NH}_{3}+\mathrm{H}_{2}$ 
- $\mathrm{RCOCOOH}+\mathrm{CH}_{3} \mathrm{CO}\left(\mathrm{NH}_{2}\right) \mathrm{COOH} \rightarrow \mathrm{RCH}\left(\mathrm{NH}_{2}\right)$ $\mathrm{COOH}+\mathrm{CH}_{3} \mathrm{COCOOH}$

- $\mathrm{CH}_{3} \mathrm{COCOOH}+\mathrm{H}_{2} \mathrm{O} \rightarrow$ Acetate $+\mathrm{CO}_{2}+\mathrm{H}_{2}$

- $\quad \mathrm{C}_{6} \mathrm{H}_{13} \mathrm{O}_{2} \mathrm{~N}$ (Leucine) $+2 \quad \mathrm{H}_{2} \mathrm{O} \rightarrow \quad \mathrm{C}_{5} \mathrm{H}_{10} \mathrm{O}_{2}$ (3-methylbutyrate) $+\mathrm{NH}_{3}+\mathrm{CO}_{2}+2 \mathrm{H}_{2}+$ ATP

- $\mathrm{C}_{6} \mathrm{H}_{13} \mathrm{O}_{2} \mathrm{~N}$ (Leucine) $+\mathrm{H}_{2} \rightarrow \quad \mathrm{C}_{6} \mathrm{H}_{10} \mathrm{O}_{2}$ (4-methylvalerate) $+\mathrm{NH}_{3}$

- $\mathrm{C}_{6} \mathrm{H}_{13} \mathrm{O}_{2} \mathrm{~N}$ (Leucine) $+2 \mathrm{H}_{2} \mathrm{O} \rightarrow \mathrm{C}_{5} \mathrm{H}_{10} \mathrm{O}_{2}$ (2-methylbutyrate) $+\mathrm{NH}_{3}+\mathrm{CO}_{2}+2 \mathrm{H}_{2}+$ ATP

- $\mathrm{C}_{5} \mathrm{H}_{11} \mathrm{O}_{2} \mathrm{~N}$ (Valine) $+2 \mathrm{H}_{2} \mathrm{O} \rightarrow \mathrm{C}_{4} \mathrm{H}_{8} \mathrm{O}_{2}$ (Methylpropionate) $+\mathrm{NH}_{3}+\mathrm{CO}_{2}+2 \mathrm{H}_{2}+$ ATP

- $\mathrm{C}_{9} \mathrm{H}_{11} \mathrm{O}_{2} \mathrm{~N}$ (Phenylalanine) $+2 \mathrm{H}_{2} \mathrm{O} \rightarrow \mathrm{C}_{8} \mathrm{H}_{8} \mathrm{O}_{2}$ (Phenylacetate) $+\mathrm{NH}_{3}+\mathrm{CO}_{2}+2 \mathrm{H}_{2}+$ ATP

- $\mathrm{C}_{9} \mathrm{H}_{11} \mathrm{O}_{2} \mathrm{~N}$ (Phenylalanine) $+{ }^{2} \mathrm{H}_{2} \rightarrow \mathrm{C}_{9} \mathrm{H}_{10}$ (Phenylpropionate) $+\mathrm{NH}_{3}$

- $\mathrm{C}_{9} \mathrm{H}_{11} \mathrm{O}_{2} \mathrm{~N}$ (Phenylalanine) $+2 \mathrm{H}_{2} \mathrm{O} \rightarrow \mathrm{C}_{6} \mathrm{H}_{6}$ (Phenol) $+\mathrm{C}_{2} \mathrm{H}_{4} \mathrm{O}_{2}$ (Acetate) $+\mathrm{NH}_{3}+\mathrm{CO}_{2}+\mathrm{H}_{2}+\mathrm{ATP}$

- $\mathrm{C}_{9} \mathrm{H}_{11} \mathrm{O}_{3} \mathrm{~N}$ (Tyrosine) $+2 \quad \mathrm{H}_{2} \mathrm{O} \rightarrow \mathrm{C}_{8} \mathrm{H}_{8} \mathrm{O}_{3}$ (Hydroxyphenylacetate) $+\mathrm{NH}_{3}+\mathrm{CO}_{2}+2 \mathrm{H}_{2}+$ ATP

\section{Side Production of Ammonia}

It is commonly assumed that decomposition of poultry litter runs according to the following reaction scheme [22]: $\mathrm{C}_{7.5} \mathrm{H}_{12.4} \mathrm{O}_{4.8} \mathrm{~N}+3.89 \mathrm{H}_{2} \mathrm{O} \rightarrow 3.7 \mathrm{CH}_{4}+2.8 \mathrm{CO}_{2}+$ $\mathrm{NH}_{4}^{+}+\mathrm{HCO}_{3}^{-}$.

Produced ammonia, dependent on $\mathrm{T}$ and $\mathrm{pH}$ conditions [23], is not transported entirely to biogas, but it is partly bound in solution. During the methane fermentation process, however, direct evolution of gaseous ammonia is also observed. Its high concentration in the fermentation chamber can strongly inhibit the fermentation process or even stop it. High ammonia content in a liquid phase of postfermented mixture $\left(\mathrm{NH}_{3}\right.$ dissolved and as $\mathrm{NH}_{4}^{+}$ions) influences its content in gas phase (biogas). Ammonia gas presence affects both the methane fermentation process course and is troublesome in respect to emission standards. Thus two different technological approaches are used. The first is based on establishing the fermentative process conditions, avoiding ammonia gas forming and thus protecting methane synthesis against inhibition. Already formed ammonium nitrogen can be bound in a form of sparingly soluble compound like $\mathrm{MgNH}_{4} \mathrm{PO}_{4} \times 6 \mathrm{H}_{2} \mathrm{O}$ (struvite) or can be removed from the anaerobic environment. The second approach focuses on selective removal of already formed ammonia gas from produced biogas before the combustion unit to avoid emissions problems. Purification of biogas before the gas engine inlet, among other factors by its cooling, makes partial removal of ammonia absorbed in water vapor condensate possible. It may happen that the concentration of $\mathrm{NH}_{4}^{+}$ions in a condensate together with the concentrations of co-present anions exceed the solubility products of various inorganic ammonium salts. Precipitation phenomena in a pipeline system providing the engine with biogas is observed, e.g., in the form of a solid ammonium carbonate $\left(\left(\mathrm{NH}_{4}\right)_{2} \mathrm{CO}_{3}\right)$ and ammonium bicarbonate $\left(\mathrm{NH}_{4} \mathrm{HCO}_{3}\right)$.

In another set of experiments during the 400day fermentation of farm poultry litter concentration of ammonium nitrogen reached $16 \mathrm{~g} / \mathrm{dm}^{3}$ and biogas production was $0.35-0.40 \mathrm{dm}^{3} / \mathrm{g}$ of volatile compounds. However, for ammonium nitrogen concentrations above $16 \mathrm{~g} / \mathrm{dm}^{3}$, the total inhibition of methane fermentation process was described in [24]. Conversion of carbohydrates decreased to $33 \%$ and proteins to $77 \%$ [24]. The methane fermentation process ran at $35^{\circ} \mathrm{C}$ and $\mathrm{pH} 8.1-8.3$. The increase in ammonium nitrogen concentration above $8 \mathrm{~g} / \mathrm{dm}^{3}$ is responsible both for the decrease of biogas productivity and for the decrease of methane content in biogas to the level $<50 \%$.

\section{Side Production of the Odour Sulphur Compounds}

During decomposition of such biomass as animal litter, a lot of gaseous compounds are co-synthesized, which together are responsible for air contamination with so-called "odor compounds." These involve, among other things, aldehydes, ketones, acids, esters, and amines. Some examples of the analytically determined sulphur compounds (present in relatively small concentrations although substantial enough for smell discomfort in the closest vicinity of the biogas plant energetically utilizing the organic biomass) that can be of key significance for social acceptance of this investment type are:

- Allyl mercaptan $-\mathrm{CH}_{2}: \mathrm{CHCH}_{2} \mathrm{SH}$

- Amyl mercaptan $-\mathrm{CH}_{3}\left(\mathrm{CH}_{2}\right)_{4} \mathrm{SH}$

- Benzyl mercaptan - $\mathrm{C}_{6} \mathrm{H}_{5} \mathrm{CH}_{2} \mathrm{SH}$

- Crotyl mercaptan $-\mathrm{CH}_{3} \mathrm{CH}: \mathrm{CHCH}_{2} \mathrm{SH}$

- Dimethyl sulphide - $\left(\mathrm{CH}_{3}\right)_{2} \mathrm{~S}$

- Diphenyl sulphide - $\left(\mathrm{C}_{6} \mathrm{H}_{5}\right)_{2} \mathrm{~S}$

- Ethyl mercaptan $-\mathrm{C}_{2} \mathrm{H}_{5} \mathrm{SH}$

- Hydrogen sulphide $-\mathrm{H}_{2} \mathrm{~S}$

- Methyl mercaptan - $\mathrm{CH}_{3} \mathrm{SH}$

- Phenyl mercaptan $-\mathrm{C}_{6} \mathrm{H}_{5} \mathrm{SH}$

- Propyl mercaptan $-\mathrm{C}_{3} \mathrm{H}_{7} \mathrm{SH}$

- Sulphur dioxide - $\mathrm{SO}_{2}$

- tert-Butyl mercaptan - $\left(\mathrm{CH}_{3}\right)_{3} \mathrm{CSH}$

- Thiocresol $-\mathrm{CH}_{3} \mathrm{C}_{6} \mathrm{H}_{4} \mathrm{SH}$

Considering the possibility of side-synthesis of the above-presented compounds, during elaboration of the project of anaerobic conversion technology of highprotein compounds one should involve, e.g., optimal strategy of the process parameters aimed at minimizing the unwanted odorous substances synthesis, co-fermentation, or advanced purification systems [25-28].

\section{Conclusions}

High-protein waste biomass as the residue from animal breeding may be a significant source of high quality cosubstrates or additives for biogas plant feeding together with classical biomass substrates. Anaerobic co-digestion of these wastes toward biomethane and/or biohydrogen providing that special technological regimes are retained can be an especially advantageous and sustainable method for such waste utilization. 
An important source for requiring utilization wastes can be dairy industry wastes covering, e.g., various forms of milk derivatives and casein. Anaerobic co-digestion of these wastes is a safe method for their efficient utilization.

Special emphasis must be put on high nitrogen content biowastes. These must be introduced into a fermentation environment gradually. One-dose injection of a large load of waste biomass with high protein content can strongly inhibit or even stop the co-fermentation process.

Another important exploitation problem during cofermentation of protein-rich wastes can be the synthesis of volatile nitrogen compounds. The fermentation system should be hermetic, but also connected with a special system of outlet ammonia (and other odors like sulphur components) removal [the authors' own research as presented in 28].

The disadvantageous effect of ammonia on anaerobic fermentation course and yield can be technologically mitigated, e.g., by the use of co-fermentation of biomass representing high nitrogen content together with representing high-carbon content.

After biogas fermentation of farm poultry litter the digestate usually contains $>6 \mathrm{~g} \mathrm{~N} / \mathrm{dm}^{3}$. Moreover, the chemical form of this nitrogen is rather easily bioassimilated by the cultivated plants. No harmful "burning" or overdosing phenomena were observed.

\section{Acknowledgements}

The work was financed by the Ministry of Science and Higher Education of Poland as the statutory financial grant of the Faculty of Mechanical Engineering SUT in 2017.

\section{References}

1. McINERNEY M.J.Anaerobic hydrolysis and fermentation of fats and proteins. In Biology of Anaerobic Microorganisms; Zehnder A.J.B. Eds., John Wiley and Sons: New York, USA, 373, 1988.

2. BUSWELL A.M., NEAVE S.L. Laboratory studies of sludge digestion. Bulletins of the State Water Survey, 30, 8 Department of Registration and Education, 1930.

3. JAKUBOWSKI T. Waste management - case study of selected district dairy cooperatives in Małopolska region, 12, 199, 2006 [In Polish].

4. ASTALS S., BATSTONE D.J., MATA-ALVAREZ J., JENSEN P.D. Identification of synergistic impacts during anaerobic co-digestion of organic wastes. Bioresource Technology, 169, 421, 2014

5. BROWN N., GÜTTLER J., SHILTON A. Overcoming the challenges of full scale anaerobic co-digestion of casein whey. Renewable Energy, 96, 425, 2016.

6. CHENG J., DING L., XIA A., LIN R., LI Y., ZHOU J., CEN K. Hydrogen production using amino acids obtained by protein degradation in waste biomass by combined darkand photo-fermentation. Bioresource Technology, 179, 13, 2015.

7. BELOSTOTSKIY D.E., ZIGANSHINA E.E., SINIAGINA M., BOULYGINA E.A., MILUYKOV V.A., ZIGANSHIN
A.M. Impact of the substrate loading regime and phosphoric acid supplementation on performance of biogas reactors and microbial community dynamics during anaerobic digestion of chicken wastes. Bioresource Technology, 193, 42, 2015.

8. FAGBOHUNGME M.O., DODD I.C., HERBERT B.M.J., LI H., RICKETTS L., SEMPLE K.T. High solid anaerobic digestion: Operational challenges and possibilities. Environmental Technology Innovations, 4, 268,2015

9. NIU Q., TAKEMURA Y., KUBOTA K., LI Y.-Y. Comparing mesophilic and thermophilic anaerobic digestion of chicken manure: Microbial community dynamics and process resilience. Waste Management, 43, 114, 2015.

10. SILES J.A., BREKELMANS J., MARTIN M.A., CHICA A.F., MARTIN A. Impact of ammonia and sulphate concentration on thermophilic anaerobic digestion. Bioresource Technology, 101, 9040, 2010.

11. ANWAR N., WANG W., ZHANG J., LI Y., CHEN C., LIU G., ZHANG R. Effect of sodium salt on anaerobic digestion of kitchen waste. Water Science and Technology, 73, 1865, 2016.

12. WEBB A.R., HAWKES F.R. The anaerobic digestion of poultry manure: variation of gas yield with influent concentration and ammonium-nitrogen levels. Agricultural Wastes, 14, 135, 1985.

13. KOSTER I.W. Characteristics of the pH-influenced adaptation of methanogenic sludge to ammonium toxicity. Journal of Chemical Technology \& Biotechnology, 36, 445, 1986.

14. KOSTER I.W., LETTINGA G. Anaerobic digestion at extreme ammonia concentrations. Biological Wastes, 25, 51, 1988.

15. OMIL F., MENDEZ R., LEMA J.M. Anaerobic treatment of saline wastewaters under high sulphide and ammonia content. Bioresource Technology, 54, 269, 1995.

16. CALLAGHAN F.J., WASE D.A.J., THAYANITHY K., FORSTER C.F. Co-digestion of waste organic solids: batch studies. Bioresource Technology, 67, 117, 1999.

17. BUJOCZEK G., OLESZKIEWICZ J., SPARLING R., CENKOWSKI S. High-solid anaerobic digestion of chicken manure. Journal of Agricultural Engineering Research, 76, $51,2000$.

18. WU G., HEALY M.G., ZHAN X. Effect of the solid content on anaerobic digestion of meat and bone meal. Bioresource Technology, 100, 4326, 2009.

19. YENIGÜN O., DEMIREL B. Ammonia inhibition in anaerobic digestion: A review. Process Biochemistry, 48, 901, 2013

20. DHAYALAN K., NISHAD FATHIMA N., GNANAMANI A., RADHAVA RAO J., UNNINAIR B., RAMASAMI T. Biodegradability of leather through anaerobic pathway. Waste Management, 27, 760, 2007.

21. WANG M., SUN X.Z., JANSSENB P.H., TANG S.X., TAN Z.L. Responses of methane production and fermentation pathways to the increased dissolved hydrogen concentration generated by eight substrates in in vitro ruminal cultures. Animal Feed Science and Technology, 194, 1, 2014.

22. TAWFIK A., EL-QELISH M. Key factors affecting on biohydrogen production from co-digestion of organic fraction of municipal solid waste and kitchen wastewater. Bioresource Technology, 168, 106, 2014.

23. HUANG W., ZHAO Z., YUAN T., LEI Z., CAI W., LI H., ZHANG Z. Effective ammonia recovery from swine excreta through dry anaerobic digestion followed by ammonia stripping at high total solids content. Biomass and Bioenergy, 90, 139, 2016. 
24. NIU Q., QIAO W., QIANG H., HOJO T., LIY.-Y. Mesophilic methane fermentation of chicken manure at a wide range of ammonia concentration: Stability, inhibition and recovery. Bioresource Technology, 137, 358, 2013.

25. MAO C., FENG Y., WANG X., REN G. Review on research achievements of biogas from anaerobic digestion. Renewable and Sustainable Energy Reviews, 45, 540, 2015.

26. JAIN S., JAIN S., WOLF I.T., LEE J., TONG Y.W. A comprehensive review on operating parameters and different pretreatment methodologies for anaerobic digestion of municipal solid waste. Renewable and Sustainable Energy Reviews, 52, 142, 2015.
27. RUGHOONUNDUN H., MOHEE R., HOLTZAPPLE M.T. Influence of carbon-to-nitrogen ratio on the mixed-acid fermentation of wastewater sludge and pretreated bagasse. Bioresource Technology, 112, 91, 2012.

28. SAKIEWICZ P., CEBULA J., PIOTROWSKI K., NOWOSIELSKI R., WILK R., NOWICKI M. Application of micro- and nanostructural multifunctional halloysite-based sorbents from Dunino deposit in selected biotechnological processes, Journal of Achievements in Materials and Manufacturing Engineering, 69, 69, 2015. 
